\title{
Determinan kelelahan kerja pada industri pembuatan mebel di Kota Medan
}

\author{
Eva Ellya Sibagariang ${ }^{1}$, Widya Yanti Sihotang ${ }^{2^{\star}}$, Hartono ${ }^{1}$, Ardian Soleh $^{1}$, Zulfahmi $^{1}$ \\ ${ }^{1}$ Fakultas Kesehatan Masyarakat Universitas Prima Indonesia \\ ${ }^{2}$ Fakultas Kedokteran Universitas Prima Indonesia
}

\begin{abstract}
ABSTRAK
Kelelahan kerja pada tenaga manusia dapat menurunkan produktivitas kinerja dan menambah kesalahan kerja pada saat melakukan pekerjaan. Hasil riset pada beberapa negara maju menunjukkan bahwa ada sekitar 10-50\% pekerja yang mengalami kelelahan kerja. Sebanyak 20\% dari penderita memerlukan pertolongan pertamaun untuk ditangani pada pelayanan kesehatan. Studi ini bertujuan untuk mengetahui faktor-faktor yang mempengaruhi kelelahan kerja pada pekerja industri rumahan pembuatan mebel. Jenis penelitian ini adalah observasional analitik dengan rancangan penelitian desain cross-sectional. Populasi pada penelitian yaitu semua pekerja yang bekerja di industri rumahan pembuatan kusen dan pintu di Kelurahan Sei Kera Kota Medan. Penentuan sampel menggunakan teknik total sampel yaitu sebanyak 33 orang. Data dianalisis dengan uji Chisquare menggunakan SPSS. Hasil penelitian menunjukkan masa kerja dan beban kerja berhubungan dengan kelelahan kerja pada pekerja industri rumahan pembuatan mebel di Kelurahan Sei Kera Kota Medan. Hasil studi juga menunjukkan tidak ada hubungan antara umur pekerja, lingkungan kerja, dan riwayat penyakit pekerja dengan kelelahan kerja. Disarankan kepada pengusaha untuk lebih memperhatikan beban kerja karyawan untuk meminimalisir resiko kecelakaan kerja.
\end{abstract}

Kata kunci: kelelahan kerja, industri mebel

\section{ABSTRACT}

Work fatigue on human labor can reduce performance productivity and increase work errors when doing work. Research results in several developed countries show that there are around 10-50\% of workers who experience work fatigue. As many as 20\% of patients require first aid to be treated at health services. This study determines the factors that affect work fatigue in furniture-making home industry workers. This type of research is an analytic observational research design with a cross-sectional design. The population in this study are all workers who work in the home industry of making frames and doors in Sei Kera Village, Medan City. Determination of the sample using the total sample technique as many as 33 people. Data were analyzed using Chi-square test using SPSS software. The results showed that the length of work and workload was related to work fatigue in the furniture making home industry workers in Sei Kera Village, Medan City. The results of the study also showed that there was no relationship between the age of the workers, the work environment, and the history of the worker's illness with work fatigue. It is recommended for employers to pay more attention to the workload of employees to minimize the risk of work accidents.

Keywords: work fatigue, furniture industry

*Alamat korespondensi: widyayantisihotang@gmail.com

DOI:10.34012/jpms.v3i2.2028

\section{PENDAHULUAN}

Untuk meningkatkan kualitas tenaga kesehatan perlu dilakukan pendidikan/pemeliharaan dan pengembangan tenaga manusia termasuk juga perlu adanya perlindungan terhadap tenaga manusia agar terhindar dari gangguan kesehatan yang mungkin dialaminya pada saat melakukan proses produksi. Perlindungan terhadap tenaga manusia harus sesuai dengan Undang-Undang RI No 39 Tahun 2009 tentang Kesehatan. Gangguan kesehatan yang sering dialami oleh tenaga manusia adalah kelelahan kerja. 
Kelelahan kerja adalah salah satu tanda/bentuk manifestasi gangguan pada tubuh pekerja. Kelelahan kerja pada tenaga manusia dapat menurunkan produktivitas kinerja dan dapat menambah kesalahan kerja pada saat melakukan pekerjaan. Tingkat produktifitas pekerja dapat disebabkan oleh gangguan fisik dan/atau psikis akan berpengaruh pada menurunnya produktifitas perusahaaan. ${ }^{1}$

Faktor yang mempengaruhi kelelahan di antaranya yaitu faktor internal dan faktor eksternal. Faktor internal mencakup usia pekerja, jenis kelamin pekerja, status kesehatan pekerja, gizi pekerja dll sedangkan faktor eksternal yaitu beban kerja, lama paparan, lingkungan fisik dll. ${ }^{2}$ WHO menyatakan kelelahan yang terlalu berat merupakan penyakit pembunuh nomor dua di dunia setelah penyakit jantung. Penelitian tentang kelelahan yang dilakukan di Jepang menujukkan bahwa dari 16 ribu tenaga kerja sebagai responden mengalami kelelahan fisik sebanyak 65\%, kelelahan mental sebanyak 28\%, dan 7\% mengalami keluhan stress. Kelelahan kerja yang biasa dialami pekerja adalah sakit kepala, kaku pada bahu dan nyeri punggung. ${ }^{3}$ Tubuh manusia mempunyai kemampuan untuk memberi tanda-tanda bahwa kegiatan yang dilakukan sudah melebihi batas kemampuan tubuh, tanda-tanda tersebut berupa kelalahan pada beberapa bagian tubuh. ${ }^{4}$

Hasil penelitian yang dilakukan di beberapa negara maju menunjukkan bahwa ada sekitar 10-50\% pekerja yang mengalami kelelahan kerja. 25\% dialami pekerja wanita dan 20\% dialami pekerja pria. Sebanyak $20 \%$ dari penderita memerlukan pertolongan pertamaun untuk ditangani pada pelayanan kesehatan. Seiring dengan bertambahnya usia maka terjadi juga perubahan-perubahan berupa kemampuan fisik, mental, psikologis dan spiritual yang dapat mempengaruhi terjadinya kelelahan pada pekerja. ${ }^{2}$ Kebisingan, panas, pencahayaan, getaran adalah faktor lingkungan dapat menimbulkan ketidaknyamana pada pekerja dan lama kelamaan akan dapat menimbulkan kelalahan. Selain faktor lingkungan tersebut faktor lain yang mempengaruhi kelelahan kerja adalah jenis kelamin, usia pekerja, status gizi pekerja, beban kerja, IMT pekerja. ${ }^{3}$ Laporan Occupational Safety and Health Administration (OSHA) menunjukkan bahwa 34\% dari pekerja yang kelihangan jam kerja disebabkan oleh kelelahan kerja. Occupational Safety and Health Administration (OSHA) menyatakan bahwa masalah terbesar pada bidang agroindustri dengan laporan dari 4 pekerja 1 di antaranya mengalami keluhan kelelahan kerja. ${ }^{1}$ Pada tahun 2013 , data International Labour Organitation (ILO) menunjukkan terdapat 2 juta korban kecelakaan kerja akibat dari kelelahan kerja yang dialami. Selain peningkatan kecelakaan kerja akibat kelelahan salah satu dampak negati lain akibat kelelahan kerja adalah penurunan produktifitas kerja dan peruahaan. ${ }^{5}$

Berdasarkan laporan Depnaker tahun 2004 tentang kecelakaan kerja di Indonesia terjadi kecelakaan sebanyak 414 kecelakaan kerja setiap hari dengan faktor penyebab kecelakaan adalah kelelahan yang cukup tinggi $(27,8 \%)$ dimana 39 di antaranya mengalami kecacatan. Kelelahan yang berat dapat berdampak buruk bagi kenyaman pekerja dan penurunan produktifitas pekerja, penurunan performansi, kurang fokus kerja, meningkatnya kesalahan-kesalahan pekerja, meningkatnya kecelakaan kerja, menurunkan ketepatan dalam melaksankan pekerjaan. Faktor yang menjadi pemicu kelalahan kerja adalah faktor lingkungan, pekerja dan pekerjaaannya. Kelelahan kerja paling sering dialami pada pekerjaan yang gerakannya berulang-ulang dan dalam waktu yang cukup lama seperti industry konveks. ${ }^{6}$

Kurangnya pengawasan di industri rumahan selama ini menyebabkan banyaknya data dari pekerja yang tidak terdaftar di Depnaker dan banyak pekerja yang tidak ada jaminan kesehatan, terlebih lagi kurangnya pengetahuan pekerja tentang keselamatan dan kesehatan kerja. Hal itu membuat peneliti tertarik untuk melakukan penelitian tentang determinan kelelahan kerja di industri rumahan pembuatan mebel di Kelurahan Sei Kera Kota Medan. Berdasarkan hasil observasi awal peneliti dengan beberapa pekerja di industri pembuatan mebel di Kelurahan Sei Kera Kota Medan ditemukan beberapa keluhan dari para pekerja, seperti merasa pusing, sakit di bahu dan leher, sebelum bekerja sudah merasa lelah dan meningkatnya dampak resiko kecelakaan kerja. 


\section{METODE}

Jenis penelitian ini adalah observasional analitik dengan pendekatan cross-sectional yaitu untuk mengetahui faktor yang berhubungan dengan kelelahan kerja pada pembuatan mebel di industri rumahan pembuatan mebel di Kelurahan Sei Kera Kota Medan. Populasi dalam penelitian ini adalah seluruh pekerja di industri rumahan pembuatan mebel di Kelurahan Sei Kera Kota Medan. Sampel dalam penelitian ini diambil dengan menggunakan total sampling di mana semua pekerja yang bekerja di industri rumahan pembuatan mebel sebanyak 33 orang. Penelitian dilaksanakan pada bulan Agustus 2019. Pengumpulan data dilakukan dengan wawancara dengan alat bantu kuesioner. Setelah data terkumpul kemudian peneliti melakukan analisis data dengan menggunakan SPSS. Analisis data dalam penelitian ini ada 2 yaitu analisis univariat bertujuan untuk menghasilkan tabel distibusi dan persentase dari setiap variabel dan analisis bivariat bertujuan untuk menghasilkan hasil uji apakah ada atau tidak hubungan variabel independen (bebas) dengan variabel dependen (terikat) dengan mengunakan uji Chi square.

\section{HASIL}

Studi ini untuk mengetahui faktor yang berhubungan dengan kelelahan kerja di industri rumahan pembuatan mebel di Kelurahan Sei Kera Kota Medan. Pada tabel 1 dapat dilihat bahwa seluruh responden industri rumahan pembuatan mebel keseluruhannya adalah laki-laki (100\%).

Tabel 1. Karakteristik responden $(n=450)$

$\begin{array}{lcc}\text { Variabel } & \text { Jumlah } & \text { Persentase } \\ \text { Jenis kelamin } & & \\ \quad \text { Laki- laki } & 33 & 100 \\ \quad \text { Perempuan } & 0 & 0 \\ \text { Umur } & & \\ \quad \text { < } 30 \text { tahun } & 19 & 57.6 \\ \quad \text { > } 30 \text { tahun } & 14 & 42.4 \\ \text { Lama bekerja } & & \\ \quad \text { < tahun } & 11 & 33.3 \\ \quad>1 \text { tahun } & 22 & 66.7 \\ \text { Riwayat penyakit } & & \\ \quad \text { Ada } & 1 & 3 \\ \quad \text { Tidak ada } & 32 & 97 \\ \text { Beban kerja } & & \\ \quad \text { Ringan } & 2 & 6.1 \\ \quad \text { Berat } & 20 & 60.6 \\ \text { Sangat berat } & 11 & 33.3 \\ \text { Lingkungan kerja } & & \\ \quad \text { Ada keluhan } & 16 & 48.5 \\ \text { Tidak ada keluhan } & 17 & 51.5 \\ \text { Kelelahan kerja } & & \\ \text { Lelah } & 31 & 93.9 \\ \text { Tidak lelah } & 2 & 6.1 \\ & & \end{array}$

Umur responden mayoritas di bawah 30 tahun yaitu sebanyak 19 responden $(57,6 \%)$ dan umur di atas 30 tahun yaitu sebanyak 14 responden $(42,4 \%)$. Lama bekerja responden mayoritas bekerja di atas 1 tahun sebanyak 22 responden $(66,7 \%)$ dan minoritas responden bekerja di bawah 1 tahun sebanyak 11 responden $(33,3 \%)$.

Mayoritas responden tidak mempunyai riwayat penyakit sebanyak 32 responden $(97 \%)$ dan responden mempunyai riwayat penyakit sebanyak 1 responden (3\%). Mayoritas responden mengalami beban kerja berat sebanyak 20 responden $(60,6 \%)$ dan responden mengalami beban kerja ringan sebanyak 2 responden $(6,1 \%)$.

Mayoritas responden mengalami keluhan pada lingkungan kerja sebanyak 17 responden (51,5\%) dan minoritas responden tidak mengalami keluhan pada lingkungan kerja sebanyak 16 responden $(48,5 \%)$. Mayoritas responden mengalami kelelahan kerja sebanyak 31 responden $(93,3 \%)$ dan responden tidak mengalami kelelahan kerja sebanyak 2 responden $(6,1 \%)$. 
Tabel 2 menunjukkan bahwa dari 33 responden diperoleh persentase tertinggi kelelahan yang dialami oleh responden adalah bertindak lamban setelah bekerja, yaitu sebanyak 30 responden (90,9\%) sedangkan persentase terendah kelelahan yang dialami responden adalah kurang memperhatikan dan enggan melihat mata seseorang setelah bekerja, yaitu masing-masing sebanyak 21 responden.

Pada tabel 3 disajikan hasil uji statistik dengan menggunakan uji Chi-square. Hasil uji menunjukkan bahwa lama kerja $(\mathrm{p}=0,039)$ dan beban kerja $(\mathrm{p}=0,000)$ berhubungan dengan kelelahan kerja di industri rumahan pembuatan mebel di Kelurahan Sei Kera Kota Medan. Variabel umur pekerja $(p=0,210)$, riwayat penyakit $(\mathrm{p}=796)$, dan lingkungan kerja $(p=0,965)$ tidak berhubungan dengan kelelahan kerja.
Tabel 2. Keadaan kelelahan kerja pekerja

$\begin{array}{lll}\text { Kelelahan kerja } & \text { n } & \% \\ \text { Sukar Berpikir } & 22 & 66.7 \\ \text { Lelah Berbicara } & 24 & 72.7 \\ \text { Gugup Menghadapi Sesuatu } & 26 & 78.8 \\ \text { Kurang Berkonsentrasi } & 22 & 66.7 \\ \text { Kurang Memperhatikan } & 21 & 63.6 \\ \text { Cenderung Lupa } & 24 & 72.7 \\ \text { Kurang Percaya Diri } & 20 & 60.6 \\ \text { Tidak Tekun saat Bekerja } & 24 & 72.7 \\ \text { Enggan Melihat Mata Sesorang } & 21 & 63.6 \\ \text { Enggan Bekerja Cekatan } & 23 & 69.7 \\ \text { Tidak Tenang Dalam Bekerja } & 24 & 72.7 \\ \text { Lelah Seluruh Tubuh } & 27 & 81.8 \\ \text { Bertindak Lamban } & 30 & 90.9 \\ \text { Tidak Kuat Berjalan } & 26 & 78.8 \\ \text { Sebelum Bekerja Sudah Lelah } & 29 & 87.9 \\ \text { Daya Pikir Menurun } & 23 & 69.7 \\ \text { Cemas terhadap Sesuatu } & 23 & 69.7\end{array}$

Tabel 3. Faktor-faktor yang berhubungan dengan kelelahan kerja

\begin{tabular}{|c|c|c|c|c|c|}
\hline \multirow{3}{*}{ Variabel } & \multicolumn{4}{|c|}{ Kelelahan kerja } & \multirow{3}{*}{$\mathrm{p}$} \\
\hline & \multicolumn{2}{|c|}{ Lelah } & \multicolumn{2}{|c|}{ Tidak lelah } & \\
\hline & n & $\%$ & n & $\%$ & \\
\hline \multicolumn{6}{|l|}{ Umur pekerja } \\
\hline$<30$ tahun & 17 & 89.5 & 2 & 10.5 & \multirow[t]{2}{*}{0,210} \\
\hline$>30$ tahun & 14 & 100.0 & 0 & 0.0 & \\
\hline \multicolumn{6}{|l|}{ Lama kerja } \\
\hline$<1$ Tahun & 9 & 81.8 & 2 & 18.2 & \multirow[t]{2}{*}{0,039} \\
\hline$>1$ tahun & 22 & 100.0 & 0 & 0.0 & \\
\hline \multicolumn{6}{|l|}{ Riwayat penyakit } \\
\hline Ada & 1 & 100.0 & 0 & 0.0 & \multirow[t]{2}{*}{0,796} \\
\hline Tidak ada & 30 & 93.8 & 2 & 6.3 & \\
\hline \multicolumn{6}{|l|}{ Beban kerja } \\
\hline Ringan & 0 & 0.0 & 2 & 100.0 & \multirow[t]{3}{*}{0,000} \\
\hline Berat & 20 & 100.0 & 0 & 0.0 & \\
\hline Sangat berat & 11 & 100.0 & 0 & 0.0 & \\
\hline \multicolumn{6}{|l|}{ Lingkungan kerja } \\
\hline Ada keluhan & 15 & 93.8 & 1 & 6.3 & \multirow[t]{2}{*}{0,965} \\
\hline Tidak ada keluhan & 16 & 94.1 & 1 & 5.9 & \\
\hline
\end{tabular}

\section{PEMBAHASAN}

Hasil studi menyimpulkan tidak ada hubungan umur pekerja dengan kelelahan kerja $(p=0,210)$. Penelitian yang dilakukan oleh Ekawati dkk. pada tenaga penjamah makanan di Instalasi Gizi RS dr. Soetijono Blora yang menyatakan bahwa tidak ada hubungan yang signifikan antara umur pekerja dengan tingkat kelelahan. ${ }^{8}$ Penelitian ini juga sejalan dengan penelitian yang dilakukan oleh Faiz dkk. (2014) yang dilakukan pada pekerja bagian operator SPBU kecamatan Ciputat yang menyatakan bahwa tidak ada hubungan usia dengan kelelahan kerja dimana diperoleh hasil p-value 0,383 , ditemukan bahwa mayoritas pekerja SPBU berumur di bawah 40 tahun sehingga hasil penelitian tidak menunjukkan adanya perbedaan yang signifikan. ${ }^{9}$ Studi oleh Saftarina dkk. (2018) menyimpulkan tidak ada hubungan usia pekerja dengan kelelahan kerja yang di alami oleh perawat. ${ }^{10}$ 
Berdasarkan survey yang dilakukan peneliti, peneliti menemukan bahwa umur responden mayoritas berumur kurang dari 30 tahun hal tersebut akan mendukung kualitas pekerja. Umur kurang dari 30 tahun merupakan umur productif setiap individu hal tersebut akan mendukung setiap individu dalam melaksanakan pekerjaan yang dia lakukan. Umur yang masih muda (produktif) akan memperkecil resiko terjadinya kelelahan kerja, dan sebaliknya semakin tua umur seseorang maka produktifitas pekerjaannya akan semakin berkurang hal tersebut juga akan dapat mengganggu stamina pekerja dalam melaksanakan pekerjaan nya dan dapat meningkatkan resiko peningkatan kelelahan kerja yang dia lakukan. Pada umumnya musculoskeletal mulai dirasakan pada umur 30 tahun dan semakin meningkat pada umur 40 tahun ke atas. Penelitian menunjukkan bahwa kekuatan otot maksimal terjadi pada saat umur antara 20-29 tahun, selanjutnya terus terjadi penurunan sejalan dengan bertambahnya umur. Pada saat umur mencapai 60 tahun, rata-rata kekuatan otot menurun sampai 20\%. Pada saat kekuatan otot mulai menurun inilah maka resiko terjadinya keluhan otot meningkat. ${ }^{11}$

Hasil studi menyimpulkan ada hubungan umur pekerja dengan kelelahan kerja ( $\mathrm{p}=0,039)$. Penelitian ini sejalan dengan penelitian yang dilakukan Mahardika dkk. (2017) di PT Pertamina (Persero) Mor VII Makassar yang menyatakan bahwa ada hubungan yang signifikan antara masa kerja/lama kerja dengan kelelahan kerja $(\mathrm{p}=0,035) \cdot{ }^{12}$ Namun hasil penelitian ini tidak sejalan dengan penelitian yang dilakukan oleh oleh Faiz dkk. (2014) yang dilakukan pada pekerja bagian operator SPBU kecamatan Ciputat yang menyatakan bahwa tidak ada hubungan masa kerja dengan kelelahan kerja. Diperoleh bahwa orang yang bekerja di atas 2 tahun akan dapat lebih beradaptasi dengan lingkungan kerja (pekerjaan yang dilakukan). ${ }^{9}$

Berdasarkan survey lapangan yang telah dilakukan peneliti, peneliti menemukan bahwa pekerja yang telah bekerja di atas 1 tahun lebih banyak mengalami kelelahan kerja dibandingkan dengan pekerja yang bekerja kurang dari 1 tahun. Hal ini terjadi karena pekerja yang bekerja di atas 1 tahun lebih memiliki banyak pekerjaan daripada pekerja yang bekerja dibawah 1 tahun. Pekerja yang bekerja di bawah 1 tahun cenderung kurang aktif dalam melakukan pekerjaan karena pekerja masih kurang paham terhadap pekerjaan yang mereka lakukan dan pekerja tersebut agak lama dalam melakukan pekerjaannya. Lama masa kerja adalah salah satu faktor yang termasuk ke dalam komponen ilmu kesehatan kerja. Pekerjaan fisik yang dilakukan secara kontinyu dalam jangka waktu yang lama akan berpengaruh terhadap mekanisme dalam tubuh (sistem peredaran darah, pencernaan, otot, syaraf, dan pernafasan). Dalam keadaan ini kelelahan terjadi karena terkumpulnya produk sisa dalam otot dan peredaran darah dimana produk sisa ini bersifat membatasi kelangsungan kegiatan otot. ${ }^{13}$

Hasil studi menyimpulkan ada hubungan beban kerja dengan kelelahan kerja $(\mathrm{p}=0,000)$. Penelitian ini tidak sejalan dengan penelitian yang dilakukan oleh Purba (2018) di mana kesimpulannya adalah tidak ada hubungan yang signifikan antara beban kerja dengan kelelahan kerja pada perawat di Rumah Sakit Vita Insani Pematang Siantar. ${ }^{13}$ Penelitian ini juga tidak sejalan dengan penelitian yang dilakukan oleh Anggorokasih dkk. (2019) tentang The Relationship Between Physical Workload And Sleep Quality With Work Fatigue In Construction Workers At PT. X City Of Semarang menunjukkan tidak ada hubungan antara beban kerja dengan kelelahan kerja. ${ }^{14}$

Berdasarkan survey lapangan, peneliti menemukan bahwa pekerjaan yang dilakukan pekerja pembuatan mebel di Kelurahan Sei Kera Kota Medan mayoritas adalah pekerjaan berat dan pekerjaan sangat berat hal tersebut akan menyebabkan penggunaan/pemanfaatan tenaga berlebih pada saat bekerja dengan demikian maka pekerja akan semakin cepat lelah pada saat bekerja. Beban kerja menentukan berapa lama seseorang dapat mengakibatkan kelelahan atau gangguan. Pada pekerjaan yang terlalu berat dan berlebihan akan mempercepat pula kelelahan kerja seseorang. Berat ringannya beban kerja yang diterima oleh seorang tenaga kerja dapat digunakan untuk menentukan berapa lama seorang tenaga kerja dapat melakukan aktivitas pekerjaannya sesuai dengan kemampuan dan atau kapasitas kerjanya bersangkutan. Penanganan bahan secara manual, termasuk mengangkat beban, apabila tidak dilakukan secara ergonomis 
akan lebih cepat menimbulkan kelelahan otot pada bagian tubuh tertentu. ${ }^{11}$ Pekerjaan yang sifatnya berat membutuhkan istirahat yang sering dan waktu kerjayang pendek. Jika waktu kerja ditambah maka melebihi kemampuan tenaga kerja dan dapat menimbulkan kelelahan. ${ }^{15}$

Hasil studi menyimpulkan tidak ada hubungan lingkungan kerja dengan kelelahan kerja $(\mathrm{p}=0,965)$. Penelitian sejalan juga sejalan dengan penelitian yang dilakukan oleh Mustofani \& Dwiyanti (2019) tentang Relationship Between Work Climate And Physical Workload With Work-Related Fatigue diperoleh nilai $\mathrm{p}=0,192$ yang artinya tidak ada hubungan antara lingkungan kerja dengan kelelahan kerja. ${ }^{16}$ Namun penelitian ini tidak sejalan dengan penelitian yang dilakukan oleh Lestari (2016) pada pekerja unit 1 boiler PJB Tanjung Awar-Awar yang menyatakan bahwa ada hubungan antara kebisingan di lingkungan kerja dengan kelelahan kerja yang diakibatkan oleh lingkungan kerja yang memiliki kebisingan di atas nilai ambang batas. ${ }^{17}$

Berdasarkan survey dan observasi pada saat penelitian, peneliti menemukan bahwa lingkungan kerja telah mendukung proses pekerjaan yang dilakukan oleh pekerja. Lingkungan kerja di industri kusen dan pintu tidak terlalu bising dan kebisingan yang dihasilkan oleh proses pengetaman tidak mempengaruhi seluruh ruangan. Kebisingan yang terjadi di lingkungan kerja hanya terjadi setiap waktu dan yang mengalami keluhan kebisingan hanyalah mereka yang melakukan pengetaman. Suhu lingkungan kerja di industri rumahan pembuatan kusen dan pintu di Kelurahan Sei Kera Kota Medan tidak terlalu tinggi sehingga hal tersebut tidak terlalu berpengaruh dengan kelelahan pekerja. Kelelahan akibat panas, terjadi karena cuaca kerja yang sangat panas, terutama tenaga kerja yang belum teraklimatisasi. ${ }^{18}$

Hasil studi menyimpulkan tidak ada hubungan riwayat penyakit dengan kelelahan kerja ( $\mathrm{p}=0,796)$. Penelitian ini juga sejalan dengan penelitian yang dilakukan oleh Azhary dkk, (2017) yang menyatakan bahwa tidak ada hubungan riwayat penyakit dengan kelelahan kerja. ${ }^{19}$ Namun penelitian ini tidak sejalan dengan penelitian yang dilakukan oleh Trinfiandy dkk (2018) pada perawat di Rumah Sakit X Jakarta Timur yang menyatakan bahwa ada hubungan antara riwayat penyakit dengan kelelahan kerja. ${ }^{20}$

Berdasarkan survey lapangan yang dilakukan peneliti, peneliti menemukan bahwa pekerja yang tidak memiliki riwayat penyakit akan menurunkan resiko untuk mengalami kelalahan kerja. Meskipun pekerja memiliki riwayat penyakit namun penyakit tersebut dialami mungkin saja sudah dalam waktu yang cukup lama dan pada saat penelitian berlangsung kondisi kesehatannya dalam keadaan baik. Selain itu riwayat penyakit yang dialami pekerja mungkin saja bukan penyakit jantung, tekanan darah tinggi, asma dan lainnya dapat mempercepat/mempengaruhi kecepatan pekerja untuk mengalami kelelahan kerja. ${ }^{18}$ Selain itu faktor lain yang mungkin menyebabkan tidak adanya hubungan antara variabel riwayat penyakit dengan kelelahan kerja adalah jumlah sampel yang kecil dan jumlah responden yang tidak seimbang antara responden yang memiliki riwayat penyakit dengan yang tidak memiliki riwayat penyakit. Jumlah responden yang memiliki riwayat penyakit lebih kecil dari jumlah responden yang tidak memiliki riwayat penyakit.

\section{KESIMPULAN}

Studi ini menyimpulkan masa kerja dan beban kerja berhubungan dengan kelelahan kerja pada pekerja industri rumahan pembuatan mebel di Kelurahan Sei Kera Kota Medan. Hasil studi juga menunjukkan tidak ada hubungan antara umur pekerja, lingkungan kerja, dan riwayat penyakit pekerja dengan kelelahan kerja. Disarankan kepada pengusaha untuk lebih memperhatikan beban kerja karyawan untuk meminimalisir resiko kecelakaan kerja.

\section{REFERENSI}

1. Asriyani N, Karimuna S.R. Faktor yang Berhubungan dengan Terjadinya Kelelahan Kerja pada Pekerja PT. Kalla Kakao Industri Tahun 2017. Jurnal Ilmiah Mahasiswa Kesehatan Masyarakat Vol.2 No.6: 1-10. 2017

2. Budiman A, Husaini, Arifin S. Hubungan Antara Umur dan Indeks Beban Kerja Dengan Kelelahan Pada Pekerja di PT. Karias Tabing Kencana. Jurnal Berkala Kesehatan Vol.1 No.2: 2016 
3. Juliana M, Camelia A, Rahmiwati A. Analisis Faktor Risiko Kelelahan Kerja pada Karyawan Bagian Produksi PT. Arwana Anugrah Keramik, Tbk. Jurnal Ilmu Kesehatan Masyarakat Vol.9 No.1. 2018

4. Melissa T, Dwiyanti E. Gambaran Kelelahan Kerja Subjektif Pada Operator Mesin Produksi Pakan Ikan. The Indonesian Journal of Occupational Safety and Health Vol.7 No.2: 2018

5. Verawati L. Hubungan Tingkat Kelelahan Subjektif Dengan Produktivitas Pada Tenaga Kerja Bagian Pengemasan di CV Sumber Barokah. The Indonesian Journal of Occupational Safety and Health Vol.5 No.1: 2016

6. Atiqoh J, Wahyuni I, Lestantya D. Faktor-Faktor yang Berhubungan dengan Kelelahan Kerja pada Pekerja Konveksi Bagian Penjahitan di CV. Aneka Garment Gunungpati Semarang. Jurnal Kesehatan Masyarakat Vol.2 No.2: 2014

7. Notoatmodjo S. Metodologi Penelitian Kesehatan. Jakarta: Rineka Cipta. 2016

8. Ekawati H, Rahmawati AY, Wijaningsih W. Faktor Determinan Kelelahan Kerja Pada Tenaga Penjamah Makanan Di Instalasi Gizi RS Dr R Soetijono Blora. Jurnal Riset Gizi Vol.4 No.2:31-38. 2016

9. Faiz N, Sumantri A, Shofwati I. Faktor-Faktor Yang Berhubungan Dengan Kelelahan Kerja Pada Pekerja Operator SPBU di Kecamatan Ciputat Tahun 2014. Fakultas Ilmu Kesehatan UIN Syarif Hidayatullah. 2015

10. Saftarina F, Mayasari D, Villia A. Analysis of Factors Correlated to Work Fatigue of Hospital Nurses in Bandar Lampung. KnE Life Sciences Vol.4 No.4: 2018

11. Tarwaka, Solikhul HA, Sudiajeng L. Ergonomi untuk keselamatan, kesehatan kerja dan produktivitas. UNIBA Press. Surakarta. 2004.

12. Mahardika P, Russeng S, Naiem MF. Determinan Kelelahan Kerja Pada Pekerja Pengisian Tabung Depot LPG PT. Pertamina (Persero) MOR VII Makassar. FKM Universitas Hasanuddin. 2017

13. Purba SIA. Pengaruh Beban Kerja dengan Kelelahan Kerja pada Rumah Sakit Vita Insani Pematangsiantar. Fakultas Kesehatan Masyarakat Universitas Sumatera Utara. 2018

14. Anggorokasih VH, Widjasena B, Jayanti S. The Relation of Physical Workload and Quality of Sleep With Fatigue of Construction Worker in PT. X City of Semarang. Jurnal Kesehatan Masyarakat Vol.7 No.4:481-487. 2019

15. Suma'mur P. Higiene Perusahaan dan Keselamatan Kerja. Jakarta: Agung Seto. 2009

16. Mustofani, Dwiyanti E. Relationship Between Work Climate and Physical Workload With Work-Related Fatigue. The Indonesian Journal of Occupational Safety and Health Vol.8 No.2: 2019

17. Lestari, DP. Hubungan Faktor Lingkungan Kerja dengan Kelelahan Kerja pada Pekerja Unit 1 Boiler PJB Tanjung Awar-Awar. Fakultas Kesehatan Masyarakat Universitas Airlangga. 2016

18. Suma'mur P. Higiene Perusahaan dan Kesehatan Kerja (HIPERKES). Jakarta: Sagung Seto. 2013

19. Azwar A, Susilowati IH, Dinar A, Indriyani K, Wirawan M. Impact of Work-related and Non-work-related Factors on Fatigue in Production/Shift Workers. International Conference of Occupational Health and Safety (ICOHS 2017), Bali, Indonesia. 2018

20. Trinofiandy R, Kridawati A, Wulandari P. Analisis Hubungan Karakteristik Individu, Shift Kerja, dan Masa Kerja dengan Kelelahan Kerja Pada Perawat di Rumah Sakit X Jakarta Timur. Jurnal Untuk Masyarakat Sehat Vol.2 No.2: 2018 